\title{
Perencanaan Penyediaan Air Bersih melalui Investigasi Geolistrik di Daerah Bacukiki, Kota Pare Pare, Sulawesi Selatan
}

\author{
Muhammad Ramli \\ Departemen Teknik Pertambangan, Fakultas Teknik UNHAS \\ ramli@unhas.ac.id
}

\begin{abstract}
Abstrak
Kota Pare-Pare dengan bentang alam yang berbukit-bukit menjadi suatu masalah dalam suplai pemenuhan kebutuhan air bersih bagi masyarakat. Oleh karena itu, diperlukan pengembangan air tanah untuk kawasan-kawasan tertentu yang sulit terjangkau dengan sistem penyediaan air bersih melalui Perusahaan Daerah Air Minum. Pengembangan sumber daya air tanah untuk mensuplai kebutuhan air bersih meliputi sejumlah tahapan, dan hal yang paling mendasar adalah keterdapatan air tanah di bawah permukaan. Metode investigasi yang sangat popular adalah pengukuran tahanan jenis batuan. Nilai tahanan jenis batuan digunakan sebagai dasar interpretasi atas keterdapatan air tanah di dalam lapisan tanah dan batuan. Sebaliknya, variasi karakteristik fisik dan kimia batuan juga dapat mempengaruhi nilai tahanan jenis. Oleh karena itu, hubungan antara jenis batuan dan nilai tahanan jenis merupakan dua hal yang menjadi obyek pertimbangan dalam kegiatan ini. Kota Pare-Pare, secara umum, tersusun atas material batuan gunung api dengan istilah resmi sebagai Batuan Gunung Api Pare-Pare (Tppv). Nilai tahanan jenis batuan tersebut bervariasi dari 14,3 - 105,0 ohm-m. Variasi nilai tersebut menunjukkan bahwa pada kedalaman tertentu terdapat lapisan pembawa air tanah, yang dapat dikembangkan menjadi sumur produksi air tanah untuk mensuplai kebutuhan air bersih bagi masyarakat.
\end{abstract}

Kata Kunci: Air Bersih; Tahanan Jenis; Batuan; Sumur Produksi; Lapisan Pembawa Air Tanah.

\section{Pendahuluan}

Keterdapatan air tanah di bawah permukaan menjadi kendala dalam mengetahui kondisi ketersediaannya dengan pasti. Oleh karena itu, perkembangan ilmu air tanah telah memformulasikan sejumlah tahapan kegitan yang perlu dilakukan secara sistematis dalam pengembangan sumber daya air tanah tersebut, yang dapat dibagi ke dalam dua kategori utama yaitu ; eksplorasi dan eksploitasi air tanah. Kategori eksplorasi meliputi pemetaan geologi permukaan, penyelidikan geofisika/geolistrik, pemboran pilot hole, dan logging geofisika. Kategori eksploitasi meliputi reaming hole (pembesaran lubang bor), konstruksi sumur, dan uji pemompaan, serta uji kualitas air.

Kegiatan survei air tanah ini merupakan investigasi kondisi air tanah dengan Metode Geolistrik sebagai bagian dari perencanaan pengembangan potensi air tanah. Kegiatan ini merupakan tahapan awal dari proses pengembangan dan penyediaan air baku. Rekomendasi dari hasil analisis data-data yang diperoleh dalam kegiatan ini menjadi acuan pada perencanaan kegiatan selanjutnya.

Upaya untuk mengembangkan potensi air tanah dilaksanakan dengan menggunakan teknologi yang tepat guna dan lebih rumit daripada pengembangan potensi air permukaan. Guna menghindari akibat yang tidak diharapkan untuk efisiensi biaya dalam rangka pemanfaatan air tanah maka perlu dilakukan penyelidikan secara detail sebelum langkah lain ditentukan. Atas pertimbangan ini maka diadakan kegiatan Survei Kondisi Air Tanah Dengan Metode Geolistrik. 
Survei ini digunakan untuk menjelaskan tentang potensi air bawah tanah guna mendukung pemenuhan kebutuhan air domestik. Kegiatan pengukuran geolistrik ini perlu ditindaklanjuti dengan pengeboran eksplorasi air tanah untuk mendapatkan informasi keterdapatan air tanah di bawah permukaan lebih akurat bilamana ada indikasi potensi air yang prospek untuk dikelola.

\section{Latarbelakang Teori}

Metode geolistrik merupakan metode yang paling umum digunakan dalam mengidentifikasi keberadaan air tanah di bawah permukaan. Metode ini didasarkan pada prinsip perambatan arus listrik dalam media batuan. Besar tahanan jenis yang terjadi sangat tergantung pada sifat fluida dan material penyusun batuan. Oleh karena itu, hubungan antara jenis batuan dan tahanan jenis listrik yang terjadi akan menjadi dasar dalam menafsirkan tentang kondisi air tanah di daerah survei.

Maksud dari pekerjaan ini adalah melaksanakan pengumpulan data dan penyelidikan potensi air tanah untuk mendukung penyediaan air baku. Seiring dengan maksud tersebut, kegiatan ini bertujuan untuk mengevaluasi kondisi lokasi pengukuran untuk diadakan pengembangan sumur air tanah. Sedangkan sasaran dari kegiatan penyelidikan geolistrik ini adalah menjadi acuan dalam upaya merencanakan pengembangan dan pemanfaatan air tanah dalam memenuhi kebutuhan akan air baku untuk air bersih secara optimal dengan memperhatikan keseimbangan air tanah dan kelestarian lingkungan. Metode geolistrik yang digunakan dalam eksplorasi ini adalah metode tahanan jenis dengan konfigurasi elektroda Metode Schlumberger. Perinsip utama dalam penerapan metode ini adalah menafsirkan kondisi hidrogeologi di bawah permukaan berdasarkan variasi nilai tahanan jenis batuan terhadap arus listrik yang diberikan.

Metode pengukuran menggunakan geolistrik tahanan jenis (resistivity) dengan konfigurasi elektroda Aturan Schlumberger. Pada konfigurasi ini arus (I) diinjeksi ke dalam tanah melalui dua elektroda arus $(\mathrm{AB})$ dan besar beda potensial $(\Delta \mathrm{V})$ yang terjadi akan terekam oleh dua buah elektroda potensial $(\mathrm{MN})$. Susunan elektroda diatur sedemikian rupa sehingga posisi elektroda arus $(\mathrm{AB})$ berada di luar dari pada elektroda potensial (MN). harus penempatan elektroda arus dan potensial diatur sedemikian rupa yaitu elektroda arus $(\mathrm{A}-\mathrm{B})$ berada di sebelah luar dan elektroda potensial $(\mathrm{M}-\mathrm{N})$ berada di sebelah dalam yang terletak pada satu garis lurus. Hubungan antara jarak konfigurasi elektroda (faktor geometri elektroda) dengan nilai tahanan listrik yang terukur menghasilkan nilai tahanan jenis semu $\left(\square_{\mathrm{a}}\right)$ batuan. Hubungan tersebut dapat ditulis dalam bentuk persamaan berikut ;

$$
\rho_{\mathrm{s}}=\pi \frac{(\mathrm{AB} / 2)^{2}-(\mathrm{MN} / 2)^{2}}{\mathrm{MN}} \frac{\Delta \mathrm{V}}{\mathrm{I}}
$$

Dimana ; $\rho_{\mathrm{s}}$ adalah tahanan jenis semu (ohm-m), AB adalah panjang bentangan elektroda arus (meter), MN adalah panjang bentangan elektroda potensial (meter), $\mathrm{V}$ adalah beda potensial (mVolt), dan I adalah kuat arus (mA).

\section{Metode}

Pelaksanaan kegiatan survei air tanah dengan metode geolistrik dilakukan sebanyak 2 titik pengukuran yaitu titik Gl-1 di Keluruhan Lemoe, dan titik GL-2 di Kelurahan Lumpue. Kecamatan Bacukiki, Kota Pare-Pare. Pengukuran dilakukan untuk mendapatkan data sounding 
terhadap nilai tahanan jenis batuan di bawah permukaan tanah. Tahapan pelaksanaan kegiatan pengukuran dapat dideskripsi sebagai berikut;

a. Penentuan titik sounding geolistrik dilakukan melalui koordinasi dengan pemilik lokasi/lahan.

b. Pengukuran diawali dengan melakukan observasi awal dan pengukuran secara umum mencakup keseluruhan rencana lokasi kegiatan.

c. Pengukuran selanjutnya didetailkan dengan tujuan hasil observasi dapat menjelaskan kondisi air tanah keseluruhan daerah survei, dengan pertimbangan utama berdasarkan kondisi geologi, hidrogeologi, dan keefektifan metode geolistrik.

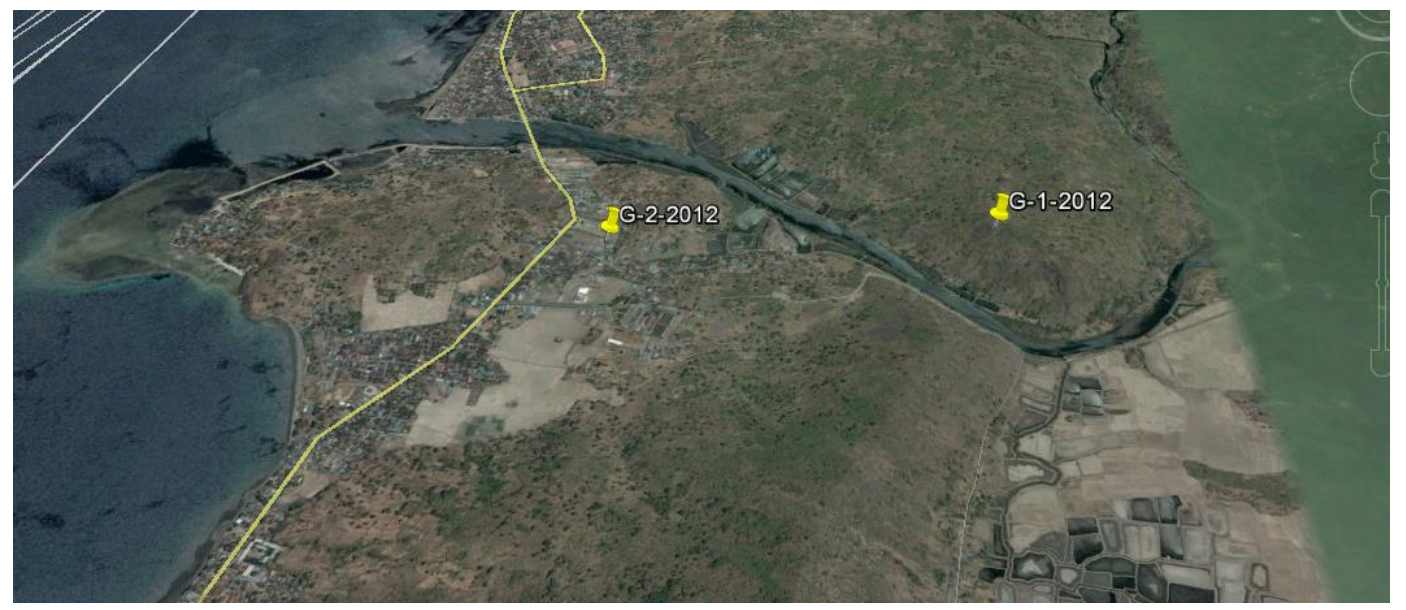

Gambar 1. Posisi Titik Pengukuran Geolistrik

Peralatan yang digunakan; Peta geologi dan hidrogeologi regional, Peta dasar berupa peta topografi berskala 1 : 50.000, Global Positioning System (GPS), Resistivity meter (Merk Naniura), Elektroda arus (2 buah), Elektroda potensial (2 buah), Kabel roll (4 roll), Hammer (4 buah), Meteran roll (2 buah), Kamera digital, dan Alat tulis serta kalkulator.

Teknik pengukuran adalah ;

a. Penentuan letak titik pengukuran sebanyak 2 titik duga yang merupakan titik yang dianggap mewakili seluruh daerah survei.

b. Pengukuran dilakukan dengan menggunakan elektroda aturan elektoda schlumberger dengan panjang bentangan elektroda arus maksimum $300 \mathrm{~m}$ atau AB/2 sebesar 150 meter.

c. Arus yang terinjeksi kedalam tanah terbangkit dari Accu (24 Volt) yang besarnya akan terbaca pada alat resistivity meter.

d. Besar beda potensial yang terjadi akan terbaca pada alat resistivity meter.

e. Arah bentangan sejajar dengan jurus perlapisan batuan, lurus, dan pada relief yang datar. 


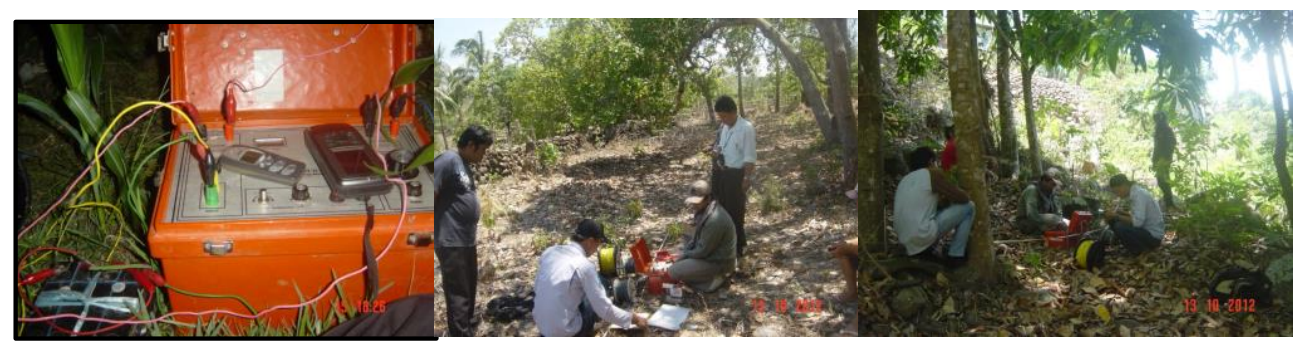

Gambar 2. Foto Geolistrik dan Kgiatan Pengukuran Geolistrik GL-1 \& GL-2

Data hasil pengkuran lapangan selanjutnya dianalisis untuk menjelaskan tentang potensi air tanah di daerah survei. Pengolahan data dan penyusunan laporan merupakan tahapan akhir dari kegiatan survei ini, yang dibagi dalam dua tahapan yaitu;

a. Interpretasi data geolistrik; Pengukuran nilai tahanan jenis semu $\left(\rho_{\mathrm{a}}\right)$ merupakan hasil yang diperoleh dari kegiatan pengukuran lapangan. Variasi nilai tahanan jenis semu tersebut kemudian diinterpretasi lebih lanjut untuk mendapatkan nilai tahanan jenis batuan (true resistivity). Dalam pekerjaan digunakan software IP2Win yang diproduksi oleh Moscow State University. Bentuk keluaran ditunjukkan jumlah lapisan tahanan jenis, besar nilai tahanan jenis sebenarnya, ketebalan setiap lapisan, kedalaman setiap lapisan, dan elevasi batas kontak antara lapisan.

b. Penafsiran data geolistrik ke kondisi hidrogeologi; Variasi nilai tahanan jenis batuan tersebut kemudian diintegrasikan dengan kondisi geologi untuk menafsirkan keterdapatan air tanah dalam akifer. Proses penafsiran ini mengacu pada sifat resistensi batuan terhadap aliran arus listrik. Output yang diperoleh pada tahapan ini adalah;

- posisi lapisan pembawa air.

- ketebalan lapisan pembawa air.

o kualitas air tanah.

○ penyebaran lateral lapisan pembawa air.

○ kondisi material di bawah permukaan.

\section{Hasil dan Diskusi}

\subsection{Kondisi Geologi}

Uraian geologi daerah survei dan sekitarnya mengacu pada hasil kompilasi Peta Geologi Lembar Pangkajene dan Watampone Bagian Barat (Sukamto, 1982) dengan hasil pengamatan langsung di lapangan. Peta Geologi Lembar Pangkajene dan Watampone Bagian Barat merupakan peta bersistem dengan skala 1:250.000. Pengamatan lapangan didasarkan pada kenampakan singkapan batuan yang terdapat pada alur-alur sungai dan tebing-tebing jalan. Hasil survei menunjukkan daerah survei air bawah tanah dan sekitarnya tersusun atas 3 kelompok batuan; yaitu Qac (Endapan Aluvium dan Pantai), Tppv (Batuan Gunungapi Pare-Pare), dan Tmcv (Batuan Gunungapi Formasi Camba), serta Tmcl (Batugamping Formasi Camba).

Materil penyusun dari kelompok batuan tersebut dapat dijelaskan sebagai berikut;

- Endapan Aluvium, Rawa dan Pantai; tersusun atas kerikil, pasir, lempung, lumpur, dan batugamping koral, terbentuk dalam lingkungan sungai, rawa, pantai dan delta. 
- Batuan Gunungapi Pare-Pare: tersusun atas tufa, breksi, konglomerat, dan lava. Batuan gunung api ini merupakan breksi gunungapi berkomponen trakit dan andesit, batuapung, batupasir tufaan, diterobos oleh retas-retas trakit-andesit.

- Batuan Gunungapi Formasi Camba; terdiri atas breksi, lava, tufa, dan konglomerat. Batugamping Formasi Camba; tersusun atas batugamping yang menjemari dengan batuan gunungapi Formasi Camba.

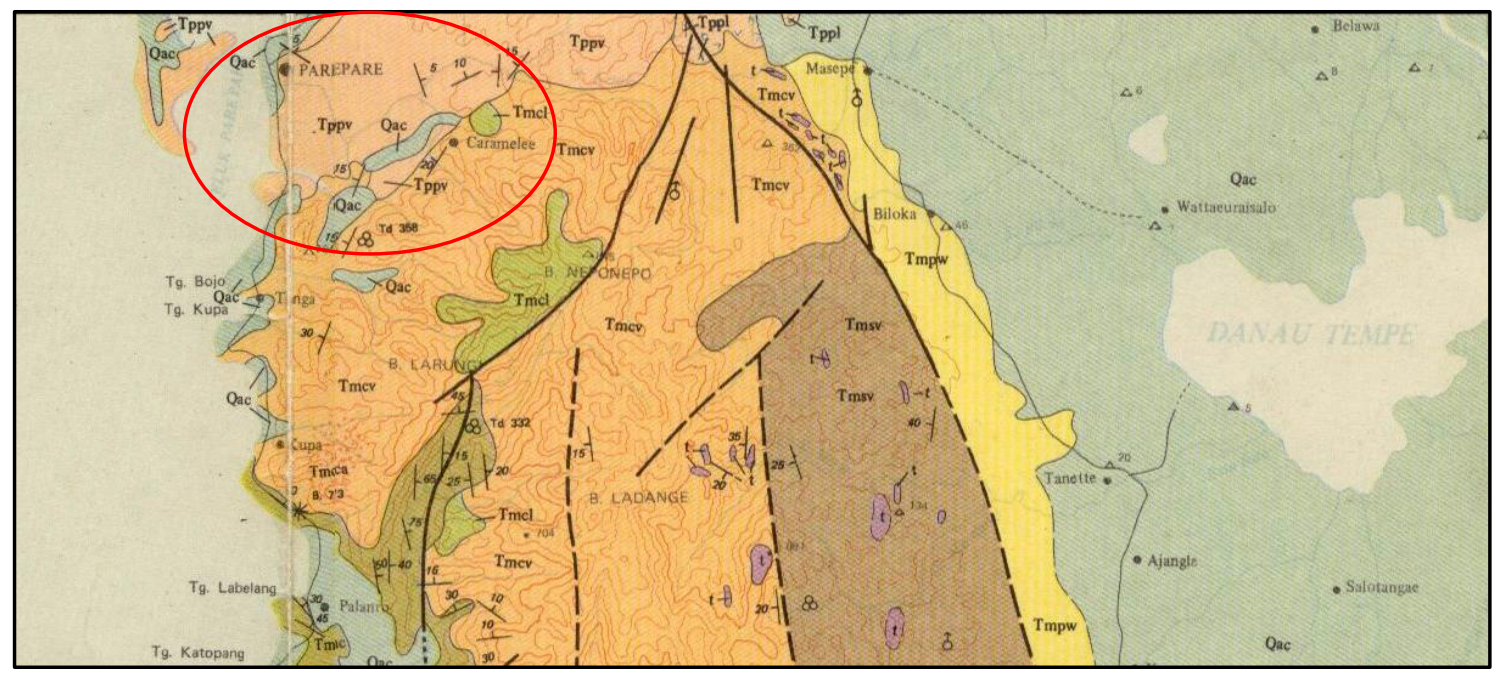

Gambar 3. Peta Geologi Pare-Pare dan Sekitarnya

(modifikasi dari Sukamto, 1982)

\subsection{Kondisi Air Tanah}

Penafsiran kondisi air tanah berdasarkan hasil survey geolistrik yang dianggap mewakili sifat lapisan batuan sampai kedalaman 150 meter. Hasil penafsiran berdasarkan kemampuan batuan untuk menghantarkan arus listrik. Terintegrasi dengan jenis batuan penyusun, maka penafsiran hasil pengukuran geolistrik disajikan dapat diuraikan seperti berikut ini.

\section{TITIK GEOLISTRIK GL-1}

Hasil intepretasi data lapangan ditunjukkan bahwa lapisan batuan yang terdeteksi terbagi atas 4 (empat) lapisan kondisi hidrogeologi yang dapat ditafsirkan sebagai berikut ;

i. Lapisan pertama: Lapisan batuan dengan nilai tahanan jenis 101,0 ohm-m yang terdapat pada $0,0-1,00 \mathrm{~m}$ di bawah permukaan tanah. Lapisan ini ditafsirkan sebagai lapisan tanah penutup sebagai hasil pelapukan batuan dibawahnya dan bongkah-bongka batuan vulkanik. Pada lapisan ini tidak terdapat air tanah.

ii. Lapisan kedua : Lapisan batuan dengan nilai tahanan jenis 14,30 ohm-m. Lapisan ini terletak pada kedalaman 1,00 - 5,0 m di bawah permukaan tanah. Lapisan ini ditafsirkan sebagai perselingan lapisan tufa lanauan dengan tufa lempungan yang tidak dapat berfungsi sebagai lapisan pembawa air tanah.

iii. Lapisan ketiga : Lapisan ini mempunyai nilai tahanan jenis $78,40 \mathrm{ohm}-\mathrm{m}$ yang terletak pada kedalaman 5,00 - 45,00 meter di bawah permukaan tanah. Lapisan ini ditafsirkan sebagai perselingan lapisan tufa lanauan - tufa lapilli yang massif yang tidak dapat berfungsi sebagai lapisan pembawa air tanah. 
iv. Lapisan keempat : lapisan ini mempunyai nilai tahanan jenis $25,90 \mathrm{ohm}-\mathrm{m}$ yang terletak pada kedalaman 45,00 - 150,00 meter. Lapisan ini ditafsirkan sebagai lapisan tufa pasiran yang dapat berfungsi sebagai lapisan pembawa air produktifitas sedang (menengah).

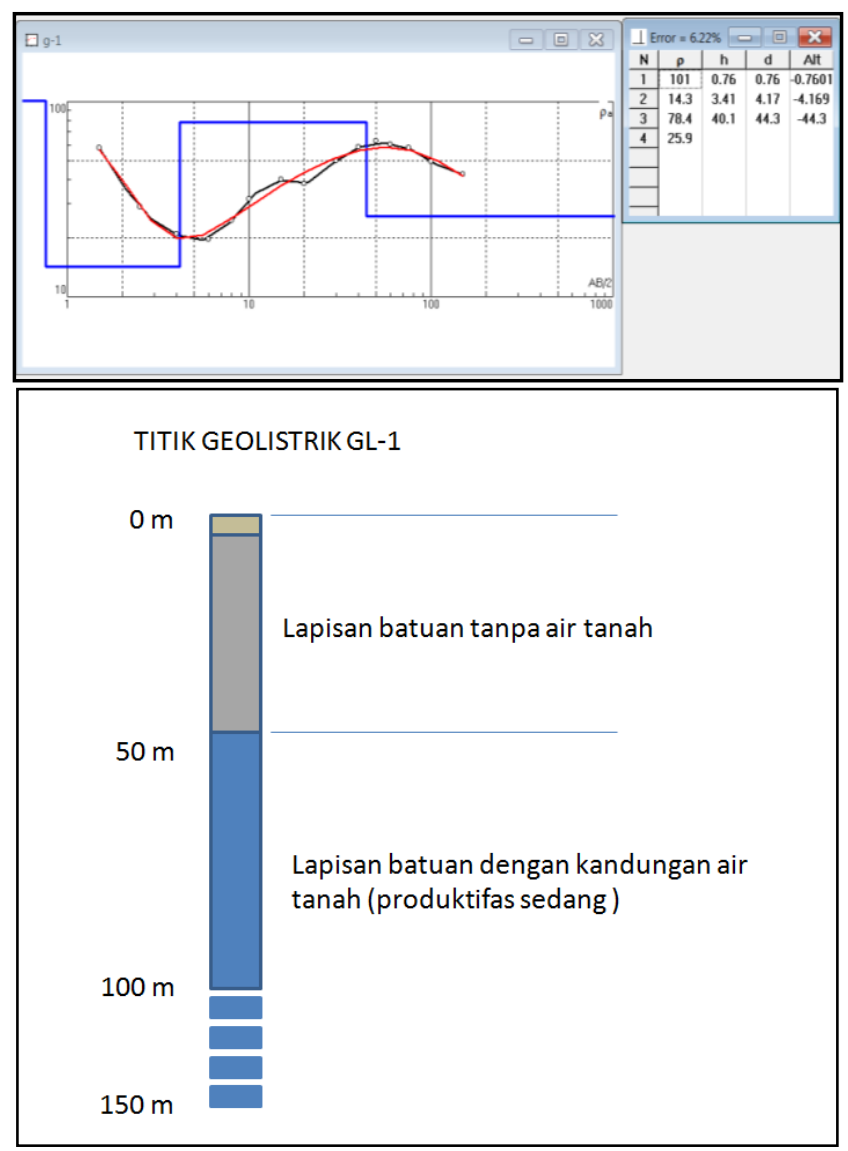

Gambar 4. Panampang hidrogeologi titik Geolistrik GL-1

\section{TITIK GEOLISTRIK GL-2}

Hasil intepretasi data lapangan ditunjukkan bahwa lapisan batuan yang terdeteksi terbagi atas 5 (lima) lapisan kondisi hidrogeologi yang dapat ditafsirkan sebagai berikut ;

i. Lapisan pertama : Lapisan batuan dengan nilai tahanan jenis 105,00 ohm-m yang terdapat pada $0,0-2,50 \mathrm{~m}$ di bawah permukaan tanah. Lapisan ini ditafsirkan sebagai lapisan tanah penutup sebagai hasil pelapukan batuan di bawahnya dan bongkah-bongkah batuan. Pada lapisan ini tidak terdapat air tanah.

ii. Lapisan kedua : Lapisan batuan dengan nilai tahanan jenis 18,40 ohm-m. Lapisan ini terletak pada kedalaman 2,50 - 4,00 m di bawah permukaan tanah. Lapisan ini ditafsirkan sebagai lapisan tufa lanuan yang tidak berfungsi sebagai lapisan pembawa air tanah.

iii. Lapisan ketiga : Lapisan ini mempunyai nilai tahanan jenis $107,00 \mathrm{ohm}-\mathrm{m}$ yang terletak pada kedalaman 4,00 - 8,00 meter di bawah permukaan tanah. Lapisan ini ditafsirkan sebagai lapisan tufa lapilli massif yang tidak dapat berfungsi sebagai lapisan pembawa air tanah. 
iv. Lapisan keempat : Lapisan ini mempunyai nilai tahanan jenis $24,30 \mathrm{ohm}-\mathrm{m}$ yang terletak pada kedalaman 8,00 - 30,00 meter di bawah permukaan tanah. Lapisan ini ditafsirkan sebagai lapisan tufa pasiran yang dapat berfungsi sebagai lapisan pembawa air tanah produktifitas sedang (menengah).

v. Lapisan kelima : Lapisan ini mempunyai nilai tahanan jenis 50,40 ohm-m yang terletak pada kedalaman 30,00 - 150,00 meter di bawah permukaan tanah. Lapisan ini ditafsirkan sebagai lapisan tufa pasiran - tufa lapilli yang dapat berfungsi sebagai lapisan pembawa air tanah produktifitas rendah.

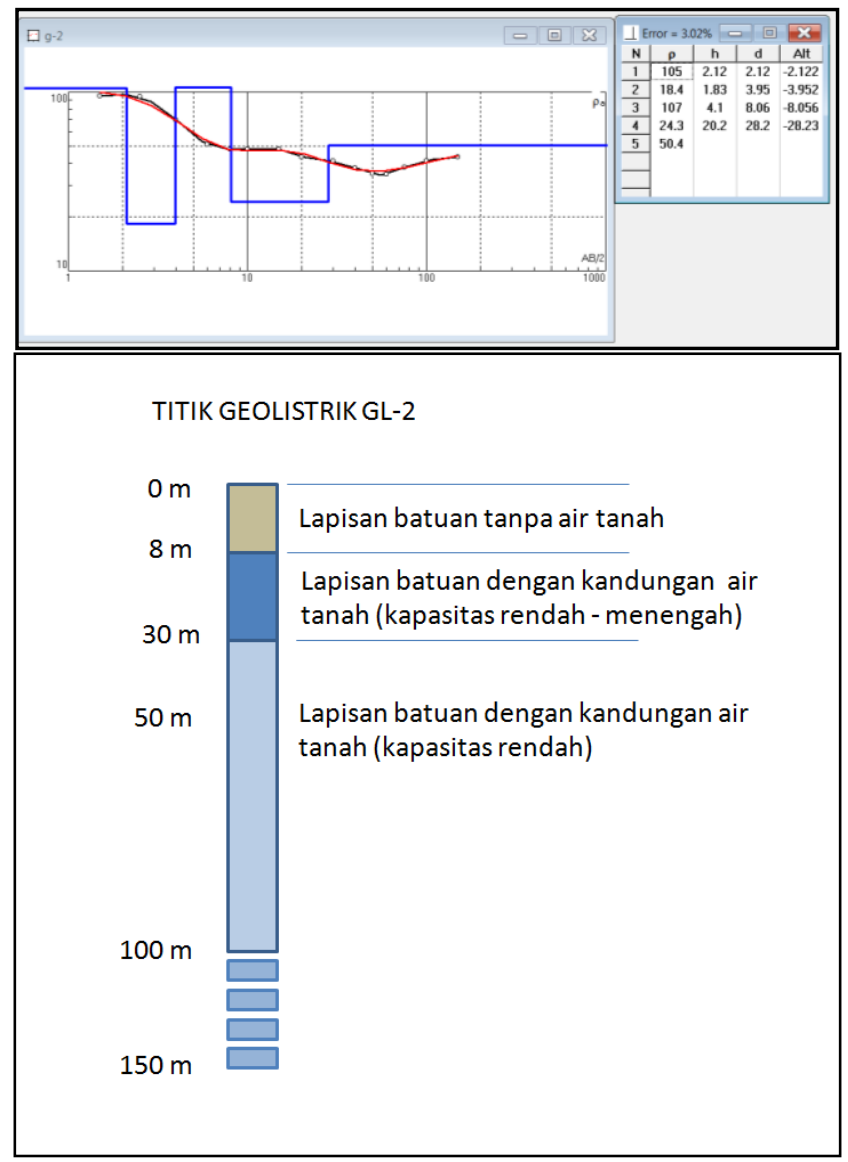

Gambar 5. Panampang hidrogeologi titik Geolistrik GL-2

\section{Kesimpulan}

Berdasarkan hasil interpretasi titik-titik sounding geolistrik, maka kondisi air tanah di daerah survei dapat direkomendasikan sebagai berikut;

a. Di sekitar Titik Geolistrik GL-1 (Daerah Bilallange - Lemoe) ; lapisan batuan yang dapat dimanfaatkan untuk sumur produksi air tanah terletak pada kedalaman 45 - $150 \mathrm{~m}$, sehingga pada titik ini dapat dilakukan pemboran air tanah hingga kedalaman 100 - 120 meter.

b. Di sekitar Titik Geolistrik GL-2 (Daerah Lumpue) ; air tanah terletak pada kedalaman 8,00 150 meter, dengan produktifitas rendah - menengah. Pemboran sumur produksi air tanah direkomendasikan hingga kedalaman 100 - 120 meter. 


\section{Ucapan Terima Kasih}

Ucapan terima kasih disampaikan kepada Tim Survei Hidrogeologi Mahasiswa Program Studi Teknik Pertambangan atas bantuannya dalam pengukuran data lapangan.

\section{Daftar Pustaka}

Asfahani, J. (2007). Geoelectrical Investigation for Characterizing the Hydrogeological Condition in Semi-arid Region in Khanasser Valley, Syria, Journal of Arid Environments, 68(1), 31-5.

Atekwana, E.A., Sauck, W.A., and Werkema, D.D. (2000). Investigation of Geoelectrical Signaturas at a Hydrocarbon Contaminated Site, Journal of Applied Geophysics, 44(2-3), 167-180

De Lima, O.A.L., and Niwas, S. (2000). Estimation of Hydraulic Parameters of Shaly Sandstone Aquifers from Geoelectrical Measurements, Journal of Hydrology, 235(1-2), 1226

Geotomo software. (2007). Res2DinV - Rapid 2-D Resistivity and IP Inversion, Online pada www.geoelectrical.com.

Kruschwitz, S., and Yaramanci, U. (2004). Detection and Characterization of the Disturbed Rock Zone in Claystone with the Complex Resistivity Method, Journal of Applied Geophysics, 57(1), 63-79.

Marescot, L., Monnet, R., and Chapellier, D. (2008). Resistivity and Induced Polarization Surveys for Slope Instability Studies in the Swiss Alps, Engineering Geology, 98(1-2), 1828.

Singh, C.L., and Singh, S.N. (1970). Some Geoelectrical Investigation for Potential Groundwater Zones in Part of Azamgarh Area of U.P, Pure and Applied Geophysics, 82(1).

Sukamto, R., 1982, Peta Geologi Lembar Pangkajene dan Watampone Bagian Barat, Sulawesi, Pusat Penelitian dan Pengembangan Geologi, Bandung.

Zohdy, A.A.R., Eaton, G.P., and Mabey, D.R. (1974). Application of Surface Geophysics to Ground Water Investigation, Techniques of Water Resources Investigation of the United States Geological Survey, United States Government Printing Office, Washington. 